Cronfa - Swansea University Open Access Repository

This is an author produced version of a paper published in:

American Journal of Philology

Cronfa URL for this paper:

http://cronfa.swan.ac.uk/Record/cronfa39454

\title{
Paper:
}

Goh, I. (in press). An Asianist Sensation: Horace on Lucilius as Hortensius. American Journal of Philology, 139

This item is brought to you by Swansea University. Any person downloading material is agreeing to abide by the terms of the repository licence. Copies of full text items may be used or reproduced in any format or medium, without prior permission for personal research or study, educational or non-commercial purposes only. The copyright for any work remains with the original author unless otherwise specified. The full-text must not be sold in any format or medium without the formal permission of the copyright holder.

Permission for multiple reproductions should be obtained from the original author.

Authors are personally responsible for adhering to copyright and publisher restrictions when uploading content to the repository. 


\section{AN ASIANIST SENSATION: \\ HORACE ON LUCILIUS AS HORTENSIUS}

Abstract. The Asianist orator Hortensius Hortalus is a partial model for Horace's critique of Lucilius in his début collection Satires 1. Much mileage is derived from the metaphor of Lucilius as a "muddy river." The appearances of Hortensius, a wealthy lover of luxury and innovator in dining habits, in Varro's De Re Rustica 3, Cicero's Brutus (where, recently deceased, he is especially memorialized) and Orator, and Catullus 65 are grist to Horace's mill. Lucilius is tendentiously linked to Asianism as well as Asia itself, and the identification is pursued through recall of Lucilius' own statements, as Horace toys with Republican texts.

\section{INTRODUCTION}

It is entirely typical of analyses of Roman verse satire that they begin with Quintilian's famous statement, "satire at least is entirely ours" (satura quidem tota nostra est, Inst. 10.1.93). ${ }^{1}$ That pride in the autochthonous origin of this genre is complicated by derivations of its literary tradition from various Greek sources, most notably (and explicitly, at Hor. Sat. 1.4.1) the Old Comedians. ${ }^{2}$ In this article, I draw together for the first time several historical and topographical strands that affect our first extant complete book of satire, Horace's Satires 1 . The argument primarily treats the intersection between the contests of rhetorical theory and the appraisal of poetry. I suggest that the literary critical aspects of Horace's Satires 1 (published c. 35 B.C.E.) owe a certain debt, so far understudied, to (among other earlier Roman Republican texts) Cicero's Brutus of c. 46 B.C.E., in that Gaius Lucilius (180-103/2 B.C.E.), Horace's predecessor in the genre, is modelled in part on Quintus 
Hortensius Hortalus (114-50 B.C.E.), Cicero's predecessor as most fêted Roman orator, "frenemy," and rival, portrayed as recently dead in the Brutus, which serves to memorialize him. The result is to complicate our reading of Horace's Lucilius.

Horace, I suggest, uses the similarities between Hortensius and Lucilius to denigrate the latter as "other." This satiric synkrisis has ironic heft: Lucilius came from the Campanian town of Suessa Aurunca, but surely moved to Rome; he was the primus inuentor, the "onlie begetter" of satire in Latin, according to Horace's implication at Satires 1.10.48. Thus, one might ask, what could be more Roman than Lucilius? I set out to show that Horace, perhaps counter-intuitively, implies that his predecessor was degenerately or luxuriously exotic. I identify, with the help of Varro's De Re Rustica and Catullus as well as Cicero's late rhetorical treatises, the Orator as well as Brutus, Hortensian interests that intersect with Horatian criticism of Lucilius. Among these: Hortensius was fabulously wealthy, with land and fishponds, and a pioneer in easy living. Hortensius' relationship with his peers, especially Cicero, who learned from and then eclipsed him, turns out to resemble what Lucilius means to Horace, who succeeds him as a satirist. Hortensius' style, according to Cicero, was "Asianist," and his decline in his later years was marked by laziness; the latter charge of indolence is part of Horace's characterisation of his predecessor, and, even though Varro elsewhere identifies Lucilius as a practitioner of the "plain style," Horace deliberately hints, through mischaracterization, misrepresentation of Lucilian verse, and the configuration of at least one Lucilian figure, Persius in Satires 1.7, at a contrarian appraisal of Lucilius' style as Asianist.

An important word of warning: Horace's opinions inevitably occupy a lot of space in the study of Lucilius, and this article is no different. Lucilius, only available to us in fragments but to Horace in writing, requires especially careful handling, not to mention some informed guesswork to make some sense (given our relative ignorance) of context and original import. Yet we can apply a 
fundamental premise: that the Lucilian and Horatian brand of satire, which the later poet tendentiously calls "practically prose" (sermoni propiora, Sat. 1.4.42), is essentially rhetorical, in that it derives its impetus from speech-acts and its background from oratorical education. Not for nothing are Horace's Satires known as Sermones, "Conversations" or "Dialogues," in the diatribe tradition; the argument of this article insists that Horace especially treats Lucilius as a practitioner of debased rhetoric. The Horatian critique-by-association of Lucilius also incorporates engagement with writers of the previous generation. These include Varro, whose De Re Rustica contains satiric elements, ${ }^{3}$ and Catullus the Neoteric poet. Looming large, also, is the unmentionable champion of the Republic, Cicero, in his incarnation as a rhetorical theorist and literary historian. The thread which connects the texts I treat is the idea that Horace, via Hortensius as he appeared for and in Cicero, Catullus, and Varro, propagated a "Lucilius" on whom he, Horace, was an improvement, who did not quite "belong," with the implicit contrast being that Horace himself did indeed belong: to Rome, to Italy, to the right side of history.

\section{MUDDY WATERS AND MODELS}

The argument depends on Horace's infamous description of the style of Lucilius (Sat. 1.4.7-11):

facetus,

emunctae naris, durus componere uersus:

nam fuit hoc uitiosus: in hora saepe ducentos, ut magnum, uersus dictabat stans pede in uno; cum flueret lutulentus, erat quod tollere uelles. 
He was witty, with an acute nose, but rough in composing his verses. For in this he was at fault: as a big deal, he would often dictate two hundred verses in an hour, as a matter of course [lit. standing on one leg.] When he flowed muddily along, there was stuff you would want to remove. ${ }^{4}$

Talking about a muddy river in Roman poetry is well known to have a Callimachean aspect. The key passage, as should be familiar, is at the end of the Hellenistic poet's Hymn to Apollo (h. 2.107-9): ${ }^{5}$

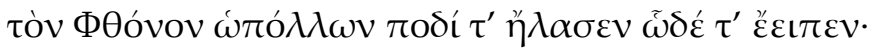

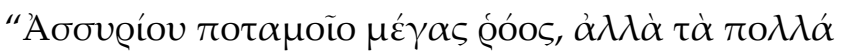

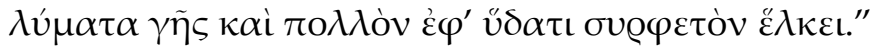

Apollo drove away Envy with his foot and spoke like this: “Great is the stream of the Assyrian river, but it drags along much refuse of earth and a lot of scum in its water."

The big water body in Callimachus' telling, which carries all this trash, is an "Assyrian river" (which the scholiast identifies as the Euphrates), six lines from the end of the hymn. Is the Euphrates a river in Asia? Strabo thinks so. ${ }^{6}$ Vergil in the Laudes Italiae ("Praise of Italy") in Georgics 2 says that Augustus is extremis Asiae iam uictor in oris, "now victor at the furthest borders of Asia" (2.170-1); six lines from the end of both Georgics 1 and 4 he is clearly on the Euphrates. ${ }^{7}$ Cicero, who held a governorship in Cilicia, repeatedly refers to the threat of a Parthian invasion across the Euphrates, at least once in conjunction with the governor of Syria, "Bibulus in Asia" (Fam. 15.1.5). ${ }^{8}$ All of this 
means that Horace, in comparing Lucilius to a muddy river, may want his readers to compare Lucilius to a specific Asian river, the slow-flowing Euphrates, filled with garbage. ${ }^{9}$

There are other rivers in Horace's Satires 1-such as the Aufidus, which flows near Horace's hometown of Venusia, a "fierce torrent" that threatens to sweep away a man at 1.1.56-60 - to which we shall return, so I want to keep the "Asian-ness" of the river on the backburner while I suggest another unstudied referent: Hortensius as piscinarius ("fish-breeder"). ${ }^{10} \mathrm{~A}$ key text for my identification is Varro's De Re Rustica 3, which at its ending treats the cultivation of fish. ${ }^{11}$ In one extract, the speaker is Axius, who is describing Hortensius' concern for tending his fishponds (R.R. 3.17.8-9):

"And," he continued, "he was no less disturbed over his sick fish than he was over his ailing slaves. And so he was less careful to see that a sick slave did not drink cold water than that his fish should have fresh water to drink. In fact he used to say that Marcus Lucullus suffered from carelessness (incuria) in this respect, and he looked down on his ponds because they did not have suitable tidal-basins, and so, as the water became stagnant (reside aqua), his fish lived in unwholesome quarters; while, on the other hand, after Lucius Lucullus had cut through (perfodisset) a mountain near Naples and let a stream of sea-water into his ponds, so that they ebbed and flowed (qui reciproce fluerent ipsae), he had no need to yield to Neptune himself in matter of fishing - for he seemed, because of the hot weather, to have led his beloved fish into cooler places, just as the Apulian shepherds are wont to do when they lead their flocks along the cattle-trails into the Sabine hills." 
Hortensius, in this account, casts an aspersion on Marcus Lucullus (here mentioned for the only time in Varro's De Re Rustica: Guiraud 1997, 114) because his ponds are stagnant and unhealthy for his fish, unlike the ponds which are able to flow through clever engineering work. We can map Hortensius onto Horace's Satires 1.4, for Hortensius criticizing (Marcus) Lucullus is like Horace on Lucilius. Horace initially describes Lucilius as static, versifying while stans pede in uno ("standing on one leg," 1.4.10), and piger scribendi ferre laborem ("lazy to do the work of writing," 1.4.12). Thus, Lucilius is like the "careless" Marcus Lucullus' stagnant fishponds, in that he contains "stuff you would want to remove" (erat quod tollere uelles, 1.4.11) - which the other Lucullus (Lucius, Marcus' brother) had, when he had literally "dug up" the channel for the seawater to refill the pools. These preferable fishponds themselves "flow" with the tides, with the result that the fish can be driven like flocks. ${ }^{12}$ It may be significant, too, that the shepherds in the simile are Apuli, since Horace identified as an Apulian (C. 3.4.9). ${ }^{13}$ Hortensius is, in this conception, playing at pastoral, which Horace also employs at points in Satires 1, through his engagement with his friend Vergil's Eclogues. ${ }^{14}$ Earlier on in Axius' description, Hortensius has been revealed to be like Horace in another way (R.R. 3.17.5-6):

Though our friend Quintus Hortensius had ponds built at great expense near Bauli, I was at his villa often enough to know that it was his custom always to send to Puteoli to buy fish for dinner. And it was not enough for him not to feed from his ponds-nay, he must feed his fish with his own hands; and he actually took more pains to keep his mullets from getting hungry than I do to keep my mules at Rosea from getting hungry, and indeed he furnished them nourishment in the way of both food and drink much more generously than I do in caring for my donkeys. 
Hortensius does not cultivate the fish for profit, or even for consumption, but buys the fish that he serves at table, ${ }^{15}$ just as Horace does not grow or farm but goes shopping: "I ask how much for greens and flour" (percontor quanti holus ac far, Sat. 1.6.112). ${ }^{16}$

But Hortensius in de Re Rustica 3 is also, and perhaps more obviously, a Lucilian figure; he does more than foreshadow Horace's persona. For Hortensius is, like Lucilius, a landowner, who in Axius' comparison has higher things on the mind than mules ${ }^{17}$ - as does Lucilius, or so Horace implies, for the inventor of satire, unlike Horace, "could be carried around his estates on a Satureian steed" (Satureiano uectari rura caballo, Sat. 1.6.59), whereas his more humble follower in the genre makes do with a mule to go to Tarentum (home of those Satureian steeds), if he so wishes (Sat. 1.6.105-6). And Hortensius is also plausibly a Horatian target. Earlier in Varro's book, Hortensius, like Lucilius, made an innovation. He brought peafowl, arguably an Eastern (or even more specifically Persian, like the Euphrates) bird, as a dish to the table (R.R. 3.6.6): ${ }^{18}$

It is said that Quintus Hortensius was the first to serve these fowl; it was on the occasion of his election as augur, and the innovation was praised at that time rather by the luxurious than by those who were strict and virtuous.

While Horace says nothing, strictly speaking, about Lucilius' enjoyment of luxury, ${ }^{19}$ it is noteworthy that peacocks are mentioned once in Satires 1. That is in Satires 1.2, the diatribe poem primarily about avoiding adultery (1.2.115-8):

num esuriens fastidis omnia praeter pauonem rhombumque? tument tibi cum inguina, num, si 
ancilla aut uerna est praesto puer, impetus in quem

continuo fiat. malis tentigine rumpi?

When you're hungry, do you disdain everything but peacock and turbot? When your loins are swollen, if a maidservant or household slave-boy is on hand for an immediate attack, would you rather burst with lust?

The appearance of a peacock might make one think of Hortensius' introduction of the bird as a meal; tentigine rumpi in line 118 seems to render a Lucilian turn of phrase into Latin, ${ }^{20}$ Hortensius was also notorious, with respect to matters of the heart, for having - after asking for the hand of the younger Cato's daughter in marriage-been offered and accepted Cato's wife, Marcia, instead. ${ }^{21}$ The ensuing scandal (which encompassed the now-wealthy Marcia's remarriage of Cato after Hortensius' death) sits well in the context of the satire because it serves both to justify the focus on avoiding married women, and to undercut the poem's moralizing position: the speaker has already used a Cato (probably the Censor) as a dispenser of praise to a young man outside a brothel, commending his choice in sexual relations with prostitutes, rather than married women (1.2.31-5). ${ }^{22}$ In any case, the giving of advice by a father-figure again links Hortensius and Lucilius, for Hortensius was Cicero's spiritual father, as he had inducted Cicero into the college of augurs (in parentis eum loco colere debebam, "it was my duty to regard him as a father," Brut. 1), the occasion which, we remember, was in Hortensius' own case marked by the first peacock banquet; Lucilius is judged by Horace as his satiric father, and in both cases the child outdoes the parent. ${ }^{23}$ 
Another way in which Hortensius resembles Horace's Lucilius is that Hortensius is made by Varro to provide a model or rival for Varro himself, in the description of keeping wild boar to fatten for market; ${ }^{24}$ here Merula speaks first, then probably Axius (R.R. 3.13.1-3):

"For on the place that our friend Varro here bought from Marcus Pupius Piso near Tusculum, you saw wild boars and roes gather for food at the blowing of a horn at a regular time, when acorns were thrown from a platform above to the boars, and vetch or the like to the roes." "Why," said he, "I saw it carried out more in the Thracian fashion at Quintus Hortensius' place near Laurentum when I was there. For there was a forest that covered, he said, more than fifty iugera; it was enclosed with a wall and he called it, not a warren, but a game-preserve (non leporarium, sed therotropium appellabat). In it was a high spot where was spread the table at which we were dining, to which he bade Orpheus be called. When he appeared with his robe and harp, and was bidden to sing, he blew a horn; whereupon there poured around us such a crowd of stags, boars, and other animals that it seemed to me to be no less attractive a sight than when the hunts of the aediles take place in the Circus Maximus without the African beasts."

Hortensius outdoes Varro with the spectacle of a banquet inside his animal enclosure, to which a "poet" Orpheus is introduced, to start the animals' feeding. It is interesting that at both Varro's and Hortensius' feeding times a horn is blown, but Hortensius is depicted as ordering a poet to do the job. That this poet doesn't actually declaim poetry is significant, ${ }^{25}$ and may be a foreshadowing of Horace's claim that his poetry, like Lucilius', should not be called poetry (Sat. 1.4.39-62), but the presence of the poet allows Axius - or rather Varro-to call the operation "Thracian," because that 
was where Orpheus had soothed wild beasts. ${ }^{26}$ Not only does the passage seem akin to Horace's satiric project (in which the excessive libertas of wild boar Lucilius is tamed for consumption in Horace's new-style sermones), but there are cultural identity dynamics at work too, because Hortensius' "Thracian" event is compared to the very Roman hunts of the aediles, in the Circus Maximus, without the foreign panthers (which is what is meant by "African beasts"). ${ }^{27}$ It is to a more detailed treatment of how such judgment of foreignness feeds into the identification between Hortensius and Lucilius that I now turn, and that requires a return to the river metaphor.

\section{ASIANIST HORTENSIUS-AND LUCILIUS?}

It is familiar that the brand of river imagery to which the description of Lucilius as lutulentus belongs is a staple of rhetorical theory, a staple whose significance I press over its (valid) Homeric and Old Comic resonances. ${ }^{28}$ Here we can invoke the opposition between two kinds of style, Atticist and Asianist. ${ }^{29}$ This is a debate in rhetorical theory that does not feature in Cicero's dialogue, De Oratore, but is present in his later works on the same subject, the Orator and Brutus; this implies that it postdates Lucilius (who is known personally to the dramatis personae of De Oratore). ${ }^{30}$ Atticism is supposed to have been restrained and sober, indebted to Lysias, while Asianism was florid and ornamental, derived from Asian teachers of rhetoric. With lutulentus, then, Horace may burden Lucilius, compared to the Asian river Euphrates, with not knowing what to cut: his work carries the excess baggage of oriental fashion, with its implicit charge of not belonging. And this is where the idea of a river, as applied to Hortensius' speech, can fit: Cicero defines one kind of Asianist flavor in rhetoric in a discussion of his sometime rival whom he has supplanted as the premier orator at Rome (Brut. 325): 
It is not so notable for its wealth of memorable phrases as for its speed and impetuosity, which is a general trait of Asia at the present, not only in the flow (flumine) of its speech, but also in the refined and delicate choice of words.

To be sure, "Cicero is adapting a definition of Asianism to fit Hortensius as well as possible." ${ }^{11}$ Also, it may seem that the swiftness of the speech/river, and the deliberate selection of vocabulary, are different from Lucilius' potentially torpid and mud-hindered flow (in the Callimachean allusion), which did not exercise - according to Horace-discretion in its choices. However, another part of Horace's claim, namely that Lucilius was garrulus ("talkative," Sat. 1.4.12), does not suggest torpidity; so, too, Cicero has provided in the same paragraph another version of Asianism:

Sententious and sprightly, it abounds in those turns of sentiment that are not so much distinguished by their weight and solidity (non tam grauibus et seueris) as by their neatness and elegance (quam concinnis et uenustis).

Again, lutulentus might seem to imply "weight and solidity" rather than an Asianist's vaunted stylishness; $; 2$ but it is noteworthy that in Satire 1.10 a supporter of Lucilius who admires his blending of Greek and Latin is allowed to defend his idol before Horace using that same word, concinnus: at sermo lingua concinnus utraque / suavior, ut Chio nota si conmixta Falerni est ("but his neat speech is smoother than either language, as if a famous Chian is mixed with Falernian," 1.10.23-4). Additionally, Cicero's description of Lucilius as a perurbanus (synonymous with uenustus, cf. Cic. 
Dom. 92, Cat. 22.2) speaks against the Horatian slur that he was silt-carrying and sluggish (De Orat.

2.25):

Gaius Lucilius, that learned (doctus) and most charming (perurbanus) man, was accustomed to say that he did not want to be read either by the unlearned or the very learned, because one group did not understand him at all, while the others perhaps understood him more than he did himself.

It is evident that Asianism might be a dodgy charge for Horace to level against Lucilius, but the later satirist still tars his predecessor by virtue of a "very learned" critique: Horace is deliberately misunderstanding him, and indeed characterizing his poetic production as extreme in various ways (such as length or libertas) - in the same way that Lucilius disdains his extreme readers. ${ }^{33}$

What is more, Asianism would not be flattering to Lucilius; in other words, Horace may be impugning him for not knowing how best to present himself. The style is a young man's business, as Cicero goes on to say about Hortensius (Brut. 325-6):

His oratorical style was the Asiatic, a manner condoned in youth, but less suited to age .... These styles of speaking (genera dicendi), as I said, are better suited to youth; in older men they lack weight (in senibus grauitatem non habent).

So, too, Cicero documents his own early training and travels in Asia ("the whole of Asia was traversed by me," Brut. 315) accompanied by the foremost orators of the region, after which the Rhodian teacher Molo had to correct "the redundancies and excess (supra fluentis) of my style, with 
its youthful impetuousness and lack of restraint, and to check it, as it were, from overflowing its banks" (Brut. 316). ${ }^{34}$ The label of "Asianist" is one most suited to youth. Yet in Satires 2.1, Horace will note that Lucilius' works enshrine "the life of an old man" (uita senis, 2.1.34). Whether this is because Lucilius actually was writing in his old age (and what would that have been really?), ${ }^{35}$ or because Lucilius' texts are old by Horace's day, Asianist style did not suit him. Again, there is a link with Hortensius: as Dugan (2005, 221-2) well identifies, Cicero in the Brutus passage defining Asianism notes that Hortensius in old age let his standards slip, exercitationem studiumque dimiserat ("he had relaxed his practice and application," Brut. 327), while refusing to give up his ill-fitting young man's style. Hortensius' laxity and refusal to keep up his training may resemble Horace's infamous judgement of Lucilius' laziness (piger, Sat. 1.4.12). ${ }^{36}$ Indeed, Lucilius' tendency, in Horace's critique, to be (literally) rooted to the spot when declaiming one minute (stans pede in uno, 1.4.7), and then running to his books to confide his secrets the next (decurrens, 2.1.32), can be compared with Hortensius' "two seemingly contradictory pathologies, change and stasis" (Dugan 2005, 221).

It is, of course, true that river imagery, even in oratory alone, can have many different significations, including word arrangement. ${ }^{37}$ In this vein Cicero recounts that Aristotle and Theophrastus recommend that the orator pay attention to prose rhythm (Orat. 228):

Hence this must be used, call it composition, or finish or rhythm as you will - this must be used if you wish to speak elegantly, not only, as Aristotle and Theophrastus say, that the sentence may not drift along never-endingly like a river (ne infiniter feratur ut flumen oratio) ... but for the reason that the periodic sentence is much more forceful than the loose. 
In fact, Asianists supposedly paid too much attention to meter: ${ }^{38}$ it is possible, for instance, to apply the designation "proto-Asianist" to Gaius Gracchus, because of his careful artistry where clausulae were concerned. ${ }^{39}$ This makes an application of the term to Lucilius especially ironic, as Horace in an infamous passage, already alluded to in this argument, has twisted himself into contortions to argue that sermones - such as he wrote, and Lucilius wrote-are prose, or conversation (sermo), not poetry (1.4.39-62). ${ }^{40}$ As part of this cheeky claim, Horace goes so far as to aver that in this kind of poetry "there is no strong spirit or force either in the words or subject matter" (acer spiritus ac uis / nec uerbis nec rebus inest, 1.4.46-7). ${ }^{41}$ Lucilius, then, seems to lack strength, and part of this may be to do with his concern with meter, whereby he followed the Old Comedians "with only their feet and meters changed" (mutatis tantum pedibus numerisque, 1.4.7), and "was content simply to enclose something in six feet per line" (ac si quis pedibus quid claudere senis, / hoc tantum contentus, 1.10.59-60). ${ }^{42}$ Certainly, in the latter statement Horace has just claimed Lucilius was not as mollis as he could be in versecomposition (1.10.58-9):43 it is unclear how much of a bad thing that is. It does still imply that Lucilius possessed a measure of mollitia, a trait apparently embraced by Hortensius, whose shtick "was famous for its transgressive theatricality." 44

But if we look at Cicero's presentation of the decline of Hortensius, we notice an interesting reflection of the river symbol in the description of his late development of weakness (Brut. 320):

Let me point out briefly what in Hortensius I venture to think was open to criticism or censure. After his consulship, seeing, I fancy, that no one else of consular rank was his rival, and making no account of those who had not held that office, he relaxed that ardor which had burned in him from his youth. He made up his mind, now that he had attained affluence (abundantia uoluit beatius), to get more enjoyment out of life, as he professed, or at all events 
to take life more easily. One year, a second, and even a third, lived in this fashion, took away something (like the slow fading of the colours in an old picture), not so much as an ordinary observer, but only a trained and intelligent critic (existimator doctus et intellegens), would perceive. But as this process went on, affecting his eloquence as a whole, and especially arresting the swift and smooth flow of his language (tum maxime in celeritate et continuatione uerborum adhaerescens), his decline from his former self began to be apparent daily.

Hortensius' decline makes his speech torpid and sticky (adhaerescens), just like a muddy river, now lacking his former fluidity-at least in the eyes of the cognoscenti (such as Cicero-or Horace knowledgeably criticizing Lucilius). ${ }^{45}$ The change comes when Hortensius decides to "live a little" and enjoy his wealth, and not only did we identify Lucilius as a wealthy landowner too, but the identification feeds into the one river image in Horace Satires 1 before the lutulentus flow of 1.4 (1.1.56-60):

eo fit

plenior ut si quos delectet copia iusto, cum ripa simul auulsos ferat Aufidus acer. at qui tantuli eget quanto est opus, is neque limo turbatam haurit aquam neque uitam amittit in undis.

This results in those who delight in a more than reasonable supply being torn off together with the bank and carried away by the keen Aufidus. But the man who asks only for the little he needs neither draws water that is swirling with mud nor loses his life in the waves. 
This river, local to Horace's birthplace, typically features in his self-mythologizing, as in the triumphal climax to the first collection of Odes, 3.30 (dicar, qua uiolens obstrepit Aufidus: "I shall be spoken of, where the violent Aufidus roars," 3.30.10). ${ }^{46}$ Thus, this application of the metaphor can be read retroactively as a criticism of both Hortensius and Lucilius, despite the former never being named in Satires 1, and the latter unmentioned until 1.4. Such men, each of whom is literally plenior copia iusto, are overwhelmed by the swift torrent of Horatian satire. ${ }^{47}$ The river can therefore be deployed to denote not just the style and quirks of the target, but also the argument which sweeps them away.

There is another Horatian satire that is relevant to my claims about Hortensius and Lucilius, and that is Satires 1.7, which depicts a scenario actually located in Asia. The poem is an anecdote which stems from the local circuit courts in the wealthy province (ditem Asiam, Sat. 1.7.19). The poem's plaintiff, who fights a lawsuit against Rupilius Rex, is named Persius. "Swollen-up" (tumidus, 1.7.7), his speech rushing "like a winter torrent" (flumen ut hibernum, 1.7.26), he is made to copy the older satirist's style, not just as a "raging torrent" but also as a "rough man" (durus, 1.7.6) - similar to Lucilius who was "rough in composing his verses" (1.4.8) - and given to "bitter talk" (adeo sermonis amari, 1.7.7) like the sermones that Horace and, before him, Lucilius wrote. ${ }^{48}$ Horace could even be insinuating that his rich Persius (1.7.4) could actually be Lucilius himself: ${ }^{49}$ he is a Graecus who gets Italo perfusus aceto ("drenched with Italian vinegar," 1.7.32), a description that could resonate with Lucilius' reputation, in Horace's eyes as well as those of his defenders, as a combiner of Greek with Latin words (1.10.20-1). ${ }^{50}$ Though Persius is Greek, he is in Asia and boasts a grubby Asian mentality, with his sycophantic fawning on Brutus as the "Sun of Asia" (1.7.23) emphasised by the in-line repetition of laudat ("he praises," 1.7.22). Likewise, the term lutulentus could be used 
rhetorically to imply moral pollution. ${ }^{51}$ And one ethical flaw in Asian values is kingship, the spectre of that "traditional scapegoat of the Republic" (Gowers 2002, 149) raised by the opening of Satires 1.7, proscripti regis ("of a proscribed king," 1.7.1) and the subject of that poem's final joke, that the judge should "kill" (iugulas, 1.7.34) this "king" - whose last name is rex, "King."

How can all this apply to Hortensius? Satire 1.7 is itself, in the words of Freudenburg $(1993,208)$, "a battle between modes of rhetoric, the extremes of Atticism and Asianism exemplified in the practices of Rex, a rugged, purebred Italian, and Persius, a half-breed whose dubious birth makes itself felt in his oratory. The entire scene is played out before Brutus, Rome's principal advocate of Atticist oratory and the addressee of Cicero's Brutus and Orator." That the judge is Brutus not only gives point to the awful pun at the end about regicide (as he had done the same for Julius Caesar), but also replays the scenario of Cicero's eponymous dialogue, where Brutus, together with Cicero and Atticus, pores over Hortensius' career as part of their examination of the literary history of rhetoric. ${ }^{52}$ So, the Asianist Persius is somewhat akin to both Lucilius and Hortensius. Of course, a complicating factor for these constructions is that Asianism was not really a strict category, but just a general tendency of two centuries of Hellenistic oratory. As a result, it is not out of the question that-just as Persius, the Asianist "raging torrent," is admitted to have spoken "in smart and fluent fashion" (salso multoque fluenti, 1.7.27), despite being durus (1.7.4)-Lucilius need not be thought of as entirely muddy and sluggish after all; a poet who "rubbed down the city with a good deal of salt/wit" (sale multo / urbem defricuit, Sat. 1.10.3-4) could indeed have done so in Asianist fashion.

Again, let me stress that this line of argument is somewhat unexpected, as Horace criticizes Lucilius' lack of refinement and elegance, traits that might be thought to be Asianist. Indeed, Lucilius was, in the judgement of Varro (as preserved by Aulus Gellius) on representatives of the genera dicendi, an exponent of the Lysias-like "plain style" (Gell. Noct. Att. 6.14.6): 
uera autem et propria huiuscemodi formarum exempla in Latina lingua M. Varro esse dicit ubertatis Pacuuium, gracilitatis Lucilium, mediocritatis Terentium.

But Marcus Varro says that true and proper examples in Latin of the styles are Pacuvius of the grand style, Lucilius of the slender, and Terence of the middle way.

The "plain style" can be mapped on to Atticism, and sal is particularly associated with that style, as in Cicero's Orator 89-90, where "whatever is witty (salsum) and wholesome (salubre) in speech is peculiar to the Attic orators," as are "jokes made on the spot (ex tempore ficta), rather than brought from home" (which would be "stale," frigida): that extempore fluency could be compared to Lucilius' dictation of two hundred lines with ease (Hor. Sat. 1.4.9-10). While Atticists despised insulsitas, "bombast," according to Cicero at Brutus 284 (Batstone 1998, 132), so perhaps Lucilius' extreme turgidity could still be Asianist, and many of the terms of the discussion can be applied to Atticists as well-for instance, Atticists could be "loose and broken" (diffluens ac solutum, Or. 234) and their speech “tossed off," abiectum (Freudenburg 1993, 151-3) - we are still presented with a difficulty. Now, Calvus and Catullus, the former a famous Atticist (and perhaps inventor of the style in Latin at Rome), were Neoteric poets whom Horace treats with the same scorn he shows Lucilius (Gowers 2012, 306), even if Horace is at pains to separate their slavish copier (simius iste, "that ape," 1.10.18) from Lucilius since the ape is unaware of Old Comedy (which Lucilius apparently followed closely in 1.4). We might compare another Neoteric poet, Furius Bibaculus, the turgidus Alpinus, ${ }^{53}$ who both is involved with a muddy river (diffingit Rheni luteum caput, "he splits the muddy head of the Rhine," 1.10.37) and "butchers Memnon" (iugulat dum Memnona, 1.10.36) 54 - a literary joke, but using the 
same Eastern verb which Persius had employed to encourage Brutus to kill Rupilius Rex. ${ }^{55}$ In a sense, then, the river metaphor is a catch-all for criticism: Lucilius and Hortensius, but also their opposites, can be rejected as "old hat." Yet is there another reason why Atticists like Calvus and his Neoteric poet brethren can be associated with Hortensius, their oratorical opposite?

\section{READING ASIAN LETTERS: LUCILIUS AND HORTENSIUS}

The surname Hortalus is rare in Latin texts. Famously, however, it is deployed by Catullus at the start of his elegiacs, in the covering letter for his translation of Callimachus' Coma Berenices, with Ortale in the vocative at 65.2, and then later repeated: Ortale, mitto / haec expressa tibi carmina Battiadae ("Hortalus, I am sending you these translations of Callimachus' poems," Cat. 65.15-16). This is conventionally interpreted as a dedication of the translation, Catullus 66, at least (and maybe the whole book) to Hortalus; it is also usually assumed that Hortalus is Hortensius Hortalus. ${ }^{56}$ Should that be the case, then here is a bona fide connection between the Asianist orator and a Neoteric poet, and indeed a link to Asia itself, especially so if the favor being returned through the poetry is Catullus' place on Memmius' entourage in Bithynia. ${ }^{57}$ Moreover, Catullus' poem excuses the tardiness of his verses (because of the recent death of his brother near Troy) by using a double version of a river, or at least a fluid, image (65.4-6):

tantis fluctuat ipsa malis-

namque mei nuper Lethaeo in gurgite fratris pallidulum manans alluit unda pedem 
[My mind] was tossed with such great evils - for recently the wave on the whirlpool of Lethe lapped at the pale foot of my brother

I am not arguing that Catullus is referring to rhetorical theory specifically, though this poem's very status as poetry (given Catullus' claimed inability to versify) is a pertinent issue. ${ }^{58}$ But there are many facets to the water imagery in Horace's Satires 1, and perhaps one of them is the presence of water when the dead - be it Lucilius or Catullus' brother - are called to mind.${ }^{59}$ Moreover, it may be telling that the word expressa (65.16), referring to the translations (the fact that they are of Callimachus is another reason we might think of a link to the lutulentus river) that Catullus has prepared, is used again (and only once in the Satires) by Horace to refer to the abuse to which Persius is subjected by Rupilius in Satires 1.7, expressa ... conuicia ("squeezed-out taunts," 1.7.28). And to continue the theme of things written and sent, Horace in that poem may be rewriting not just Catullus but also Lucilius. For Cicero had Crassus continue his praise of Lucilius as perurbanus (quoted above) with further information about his desired readership (De Orat. 2.25):

About this he also wrote, "I do not care for Persius to read me," for this man was - as we knew - just about the most learned of all our compatriots, and "I want Laelius Decimus" (who we understand was a good and not unlettered man, but nothing compared to Persius).

Pliny the Elder offers a different version of this restriction, in which Lucilius claims "I do not want Persius to read these things, I want Junius Congus to" (nec doctissimis. Persiumue haec legere nolo, Iunium Congum uolo. quod si hoc Lucilius, qui primus condidit stili nasum, Plin. N.H. praef. 7). ${ }^{60}$ Either way, Lucilius seems to have something against Persius. But it is then a joke on Horace's part to make 
one of the court antagonists in Satires 1.7 a man named Persius, who apes Lucilius closely enough to have read him, as Lucilius had not wanted a different Persius so to do. ${ }^{61}$

Horace in fact may be choosing to exploit his readers' half-forgotten memories of Lucilian poetry in his critique. ${ }^{62}$ Another fragment seems to record somebody's refusal, probably the poet's as his name appears here, to decamp to Asia (650-1 Warmington =671-2 Marx):

publicanus uero ut Asiam fiam, ut scripturarius pro Lucilio, id ego nolo et uno hoc non muto omnia.

But that I might go to Asia and become a tax-collector, that I might be a tax-farmer instead of being Lucilius? I do not want that and I do not exchange everything for that one thing.

Now, this fragment, we know from Nonius, appeared in Book 26, the poet's first chronologically, and the prominent mention of the author's name has no precedent in extant literature, ${ }^{63}$ so it has a chance of being programmatic, ${ }^{64}$ and as such may have been fairly familiar to those who knew their Lucilius. Therefore, we must try to parse the poet's refusal. This fragment may enshrine an individualistic response to the Lex Sempronia frumentaria of Gaius Gracchus from 123 B.C.E., the first to govern Asian tax-collection directly from Rome, assigning it to equites and thus making them a political force ${ }^{65}$ This refusal shows the rejection of travel, wealth and exchange. But the poet is also espousing a turn away from political acts and the coalface of the Gracchan agricultural reform.

A rejection of politics is an Epicurean trait that is part of ataraxia, a philosophy that is a prominent motivation for Horace in Satires 1, to the extent that he makes Lucilius something of a Stoic. ${ }^{66}$ If Lucilius, an eques, disclaimed responsibility for the power grab by his class, then we may 
have to question his place in society, and in particular whether he pre-empted Horace in disdaining politics despite being friends with the élite. On the issue of popularity, though, we may compare the fluctuating reception of Hortensius. Cicero notes that there was a period when "Hortensius had all but vanished from the forum" (Brut. 323), but before that decline when he was usurped in oratorical standing by Cicero, he had "played a leading role" (Brut. 317):

And with good reason too, since a great throng of people and the din of the forum (concursus hominum forique strepitus) call for an orator of animation, of fire and action and full voice.

Hortensius' popularity in the first half of his career makes him antithetical to Horace, who does not want to be read by a crowd (Sat. 1.10.74-5). ${ }^{67}$ Yet Cicero had been keen to downplay popular opinions regarding his rivalry with Hortensius (Brut. 2), while Horace makes much of writing in the same genre as Lucilius had (Sat. 1.4.55-6). Hortensius' reticence and decline in later life were no splendid isolation: his re-emergence led to collaboration with Cicero, constrained by a law that limited speaking time for defence attorneys and thus required "novelty of treatment" (Brut. 324, with Garcea and Lomanto 2014, 154-5) - perhaps an anticipation of curtailed Horatian satire. So too, Cicero (Brut. 6) and Horace (Sat. 1.10.68-71) both imagined, in slightly different ways, what Hortensius and Lucilius respectively would do if put into the present day, and the Satires 1.10 passage makes Lucilius into an anxious Horatian figure.

The Gracchan creation of an equestrian power base, of which the Lex Sempronia frumentaria was a part, led to the tumult of the Civil Wars (Varro, De Vita Populi Romani, fr. 114 Riposati): 
He encouraged them to hope that they would pay no more than they wanted [C. Gracchus' lex frumentaria]; he unfairly handed the jury-courts over to the equestrian order and made the citizen body two-headed - the origin of the civil discords (discordiarum ciuilium fontem).

The issue is a live one for Horace writing in those wars' midst. ${ }^{68}$ But Hortensius and Cicero had discussed it too (Brut. 329):

Many a time we lamented together the disasters impending, seeing the threat of civil war in the ambitions of individuals in self-interest (cum belli ciuilis causas in priuatorum cupiditatibus inclusas), and the hope of peaceful adjustment absent from public policy.

I am far enough into speculation here that I will not try the argument, inspired by the historical context of the bellum Siculum against the Pompeians in the years around the publication of Horace's Satires 1 (as outlined by Du Quesnay 1983, 21-3), that Hortensius' prior stance against Pompeius Magnus being given the command in Asia in 66 B.C.E. (addressed by Cicero in his Pro Lege Manilia) is an issue that Horace has in mind ${ }^{69} \mathrm{I}$ want simply to note that cupiditates, "pleasures" in the sentence just quoted from the Brutus, are the domain of luxury, and Lucilius' statement in the publicanus fragment is one of self-reference. His self-interest is somewhere where a critic might end up "seeing the threat of civil war." Thus Horace could tendentiously be using the vague recollection that Lucilius said something about not going to Asia to argue more or less the opposite: that he went there in spirit, so to speak..$^{70}$

We can now return to the theme of writing, because the Lucilian fragment $650-1$ Warmington $=$ 671-2 Marx actually is close to the bone for Horace: scripturarius in this Lucilian fragment indicates a 
debased version of a "writer" - a scriba as Horace was. ${ }^{71}$ What kind of writing is Lucilius refusing to do? Communication by letter back to Rome was the raison d'être of these Asiatic tax official jobs. ${ }^{72}$ The probable presence of letters in Lucilius' corpus, most often asserted with reference to Book 5,73 could make his poetic production part of his job-or rather, the job he did not take. The script- of the word scripturarius at least hints that everything in the world of satire returns to literary concerns. In this sense Horace is a failed Lucilius: he had to take and indeed keep the scriba job in order to get by. Yet not only are there no letters in Horace's Satires 1-Vergil and Varius, when recommending Horace to Maecenas, merely dixere quid essem, "said what I was" (1.6.55)-Horace, in the end, isn't even doing the writing himself: haec subscribe libello ("append this to my little book," 1.10.92), he orders his subordinate, with the imperative of a compound of scribere implying that the slave or pupil puer must do the dirty work. ${ }^{74}$

Horace, far from telling the truth about Lucilius, creatively misuses him for his own ends by tweaking Lucilius' own preoccupations. ${ }^{75}$ That is why we can wonder whether Lucilius' work was not as rough and ready as Horace makes it out to be. Two Lucilian fragments at least propose a different ethos, of simplicity and brevity: the promise that "nevertheless I shall attempt to write a summary reply in a few words" (summatim tamen experiar rescribere paucis, 1063 Warmington = 1027 Marx), ${ }^{76}$ and the question "why should I try to write you roundabout ramblings?" (quid tibi ego ambages ambi<t>u<s> scribere coner?, 1192 Warmington = 1281 Marx). ${ }^{77}$ These lines, despite their speaker being unknown, suggest the possibility that speaking to the point was a feature canvassed in Lucilius' own work. Or rather, writing to the point: for both fragments involve the physical act of putting words down in writing. But then, it is significant that Cicero (Orat. 132) says that "Hortensius spoke better than he wrote" (dicebat melius quam scripsit, Hortensius)..$^{78}$ As Steel (2007, 244) comments, "it seems that the charm of this speaking was not well represented by written texts." 
Hortensius is weakened on paper, and indeed even more than that: for it was after the trial of Verres when Cicero usurped his position as leader of the Roman bar. On that occasion, as Cicero claims in Orator (again a work dedicated to Brutus), that nobis pro familiari reo summus orator non respondit Hortensius ("Hortensius, a consummate orator, made no reply in defence of his friend whom I brought to trial," Orat. 129). ${ }^{79}$ Likewise, Lucilius does not seem to speak outright in Horace Satires 1, where he is never given any direct speech, or even quoted directly (as far as we know). ${ }^{80}$ In a similar vein, Cicero claims that Brutus should "note how closely my career followed (simus ... persecuti) the very footprints of Hortensius" (Brut. 307). ${ }^{81}$ This admission of following is what Horace says he did for Lucilius (sequor hunc, Sat. 2.1.34), which is itself grounds for considering the Pest of Satires 1.9 , who first follows $(1.9 .6,1.9 .19)$ then is followed by Horace $(1.9 .42-3)$ as a version of Lucilius (Ferriss-Hill 2011, 439-40, 449). Yet as Cicero has Brutus observe, Hortensius never had the last word in a case shared with Cicero, leaving it to his colleague (Brut. 190):

When he was associated in cases with you (I know because I was often present in your conferences) the concluding speech, where there was the greatest opportunity for effect, he always left to you.

Horace could be said to deny Lucilius the last word in the one place where he seems to replicate exactly Lucilius' phraseology: the close of the same satire, 1.9, where Lucilius' quotation of a

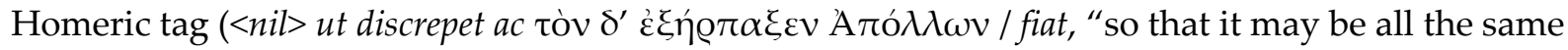
and become a case of 'and Apollo snatched him away'," 267-8 Warmington = 231-2 Marx, utilizing Hom. Il. 20.443) is rendered in Latin as sic me seruauit Apollo ("so Apollo saved me," Sat. 1.9.78). ${ }^{82}$ But it is noteworthy for my purposes that the text from which Lucilius has appropriated the line-end is 
Homer's Iliad, which described events in the Trojan War, fought of course in Asia. Even in being outdone by Horace, Lucilius is figured as having something to do with the East.

\section{CONCLUSION}

This examination has proposed a new reading of Horace's Satires Book 1, with a wealth of new details involving the river image which was used to denigrate Lucilius, set in a context of Republican Roman culture, particularly as they apply to the orator Quintus Hortensius Hortalus. Hortensius' presentation in, variously, Varro's De Re Rustica 3, Cicero's Brutus and Orator, and Catullus 65, serves for Horace as an important if partial comparandum for Lucilius. Hortensius' interest in keeping fish in ponds added new dimensions to the comparison of Lucilius to a sluggish water body, with Hortensius depicted in both a Horatian and a Lucilian role in Varro. So, too, Hortensius' hunting spectacle, a model for Varro, participates in cultural identity questioning, and Lucilius, compared by Horace to an Asian river, the Euphrates, and possessing certain traits of Asianist style, can be read as akin to the Asianist orator Hortensius. Greed, wealth, and luxury link Horace's Lucilius and Cicero's Hortensius in Horace's Satires 1, via iterations of the river image in 1.4, 1.10, and 1.1, 1.6 with its landed gentry idea, 1.2 with its fleeting appearance of a peacock and hint of scandal, and particularly 1.7 with its protagonist Persius. So, too, in that last poem Brutus sits in judgment on the Asian law court just as he had been an interlocutor in Cicero's Brutus and Orator, picking over Hortensius' career as an Asianist orator and, especially, his decline which makes him stylistically lutulentus, "muddy," like Lucilius, and which is exacerbated by his speaking style.

Varro's assessment of Lucilius as a practitioner of the "plain style," and thus an Atticist, is in turn complicated by Hortensius' association with Catullus in Asia; Lucilius' own words regarding Asia 
are turned against him in Horace's critique. And Hortensius' weaknesses in Cicero's estimation (including effeminacy, unsuitability for being read, silence in the Verres case, yielding of the last word) map on to Lucilian ones, as Horace reduces Lucilius to the status of a cipher and has his own way with his predecessor's reputation.

This argument highlights the slippery nature of literary criticism, focused as it always has been on arbitrary cultural categorisation, evocation of personality, and questions of definition, just as much as on defamation. It might be objected that too much of the original context of our texts has been lost to be of service-not just Lucilius but Cicero's Hortensius as well, for instance. And I appreciate that it may stretch the bounds of credulity for some to accept that Horace has in mind both works of Cicero to which he never overtly refers and specific lines of Lucilius which have additionally survived in the partial and skewed remains we have today, even if the particular claims I have made concern statements which were likely to be programmatic by the older satirist. Nonetheless, I hope we can tentatively agree that the political dimensions in the penumbra of Horace's Satires are akin to those surrounding the eulogy of Hortensius in the Brutus, for despite the repeated claims of friendly rivalry with Hortensius, Cicero had been, as his private letters reveal, skeptical of Hortensius' attitude toward his exile, charging him with betrayal. ${ }^{83}$ We might relate that turbulent relationship, somewhat sanitized for the Brutus, to Horace's ambivalence toward Lucilius, let alone regarding another major influence in the poet's sphere: the dedicatee of Satires 1 (and third word of the book), Maecenas. One wonders whether the one river in Satires 1 not yet mentioned in this article, Etrusci / quale fuit Cassi rapido ferventius amni / ingenium ("just like Cassius the Etruscan whose inspiration was more fevered than a raging torrent," 1.10.61-3), compared to Lucilius' two hundred lines before and after dinner, is a jokingly substituted stand-in for the poet's shadowy patron who is also Etruscan, a dabbler in verse, and - like Hortensius -inordinately wealthy. ${ }^{84}$ 
Believe that or not, the broad picture ought to stand: acknowledging the hints of an old rivalry (Cicero $\sim$ Hortensius) being configured into a new one (Horace $\sim$ Lucilius) in Satires 1 has opened up new avenues of interpretation. It is hoped that such suggestions and speculations as presented here form a spur for further work, for instance on the influence on Horace's poetics of the discredited but influential Cicero, ${ }^{85}$ and allow us a more intense appreciation of how Horace continues to manipulate the whole gamut of Republican literature both in and beyond his début collection, as in his later strictures on Plautus. ${ }^{86}$ Fundamentally, realizing the presence of Hortensius in the make-up of Horace's Lucilius allows us to recognize ever better the ways in which the apparently coolheaded, responsibly moderate Horace models his Satires 1 appraisal of his predecessor on intermediary Republican theoretical and aesthetic discussions, whereby literary personages engaged at arm's length with, distanced themselves from, and memorialized forever their own associates, friends, and rivals. ${ }^{87}$

\section{BIBLIOGRAPHY}

Anderson, W. M. 1982. Essays in Roman Satire. Princeton: Princeton University Press.

Andrews, N. E. 1998. "Philosophical Satire in the Aetia Prologue." In Genre in Hellenistic Poetry, ed.

M. A. Harder, R. F. Regtuit, and G. C. Wakker, 1-19. Groningen: Egbert Forsten.

Armstrong, David. 1986. “Horatius eques et scriba: Satires 1.6 and 2.7.” TAPA 116: 255-88.

Arnott, W. G. 2007. Birds in the Ancient World from A to Z. London: Routledge.

Bakola, Emmanuela. 2010. Cratinus and the Art of Comedy. Oxford: Oxford University Press.

Barchiesi, Alessandro. 2003. "The Search for the Perfect Book: A PS to the New Posidippus." In The

New Posidippus: A Hellenistic Poetry Book, ed. Kathryn Gutzwiller, 320-42. Oxford: Oxford

University Press. 
Batstone, W. W. 1998. “Dry Pumice and the Programmatic Language of Catullus 1." CP 93: 125-35.

Bowersock, G. W. 1979. “Historical Problems in Late Republican and Augustan Classicism.” In Le classicisme à Rome aux 1ers siècles avant et après J.-C.: neuf exposés suivis de discussions, 57-75. Vandoeuvres-Genève: Fondation Hardt.

Brink, C. O. 1963. “Horace and Varro." In Varron: six exposés et discussions, 175-200. VandoeuvresGenève: Fondation Hardt.

Brown, P. M. 1993. Horace: Satires 1. Warminster: Aris and Phillips.

Cameron, Alan. 1995. Callimachus and his Critics. Princeton: Princeton University Press.

Cavarzere, Alberto. 2000. Oratoria a Roma: storia di un genere pragmatico. Rome: Carocci.

Chahoud, Anna. 2011. “The Language of Latin Verse Satire.” In A Companion to the Latin Language, ed. James Clackson, 367-83. Oxford: Wiley-Blackwell.

Chillet, Clément. 2016. De l'Étrurie à Rome: Mécène et la foundation de l'Empire. Rome: École française de Rome.

Christes, Johannes. 1971. Der frühe Lucilius: Rekonstruktion und Interpretation des XXVI. Buches sowie von Teilen des XXX. Buches. Heidelberg: C. Winter. . 1986. “Lucilius.” In Die römische Satire, ed. Joachim Adamietz, 57-122. Darmstadt: Wissenschaftliche Buchgesellschaft.

Cichorius, Conrad. 1908. Untersuchungen zu Lucilius. Berlin: Weidmannsche Buchhandlung.

Coleman, K. M. 1990. "Fatal Charades: Roman Executions Staged as Mythological Enactments." JRS 80: $44-73$.

Connolly, Joy. 2007. “The New World Order: Greek Rhetoric in Rome.” In A Companion to Greek Rhetoric, ed. I. Worthington, 139-65. Oxford: Wiley-Blackwell. 
Corbeill, Anthony. 2004. Nature Embodied: Gesture in Ancient Rome. Princeton: Princeton University Press.

Courtney, E. J. 1993. The Fragmentary Latin Poets. Oxford: Clarendon Press. 1999. Archaic Latin Prose. Atlanta: Scholars Press.

Crawford, J. W. 1994. M. Tullius Cicero: The Fragmentary Speeches. Atlanta: Scholars Press.

Cucchiarelli, Andrea. 2001. La satira e il poeta: Orazio tra Epodi e Sermones. Pisa: Giardini.

Cuypers, Martine. 2010. “Historiography, Rhetoric, and Science: Rethinking a Few Assumptions on Hellenistic Prose." In A Companion to Hellenistic Literature, ed. J. J. Clauss and Martine Cuypers, 317-36. Oxford: Wiley-Blackwell.

Daly, Gregory. 2002. Cannae: The Experience of Battle in the Second Punic War. London: Routledge.

Delignon, Bénédicte. 2006. Les satires d'Horace et la comédie gréco-latine: une poétique de l'ambiguité. Louvain: Peeters.

Doody, Aude. 2017. "The Authority of Writing in Varro's De Re Rustica." In Authority and Expertise in Ancient Scientific Culture, ed. Jason König and Greg Woolf, 182-202. Cambridge: Cambridge University Press.

Douglas, A. E. 1966. Cicero: Brutus. Oxford: Clarendon Press.

Dugan, John. 2005. Making a New Man: Ciceronian Self-fashioning in the Rhetorical Works. Oxford: Oxford University Press.

Du Quesnay, I. M. le M. 1983. “Horace and Maecenas: The Propaganda Value of Sermones I.” In Poetry and Politics in the Age of Augustus, ed. Tony Woodman and David West, 18-58. Cambridge: Cambridge University Press. 2012. “Three Problems in Poem 66." In Catullus: Poems, Books, Readers, ed. I. M. le M. Du Quesnay and Tony Woodman, 153-83. Cambridge: Cambridge University Press. 
Dyck, A. R. 2008. “Rivals into Partners: Hortensius and Cicero.” Historia 57: 142-73.

Edwell, Peter. 2013. “The Euphrates as a Boundary between Rome and Parthia in the Late Republic and Early Empire." Antichthon 47: 191-206.

Feldherr, Andrew. 2011. “The Intellectual Climate.” In A Companion to Catullus, ed. M. B. Skinner, 92-109. Oxford: Wiley-Blackwell.

Fantham, Elaine. 2003. “Three Wise Men and the End of the Roman Republic.” PLLS 11: 96-117.

Feeney, Denis. 2002. “The Odiousness of Comparisons: Horace on Literary History and the Limits of Synkrisis." In Horace and Greek Lyric Poetry, ed. Michael Paschalis, 7-18. Rethymnon: Department of Philology, University of Crete.

Ferriss-Hill, J. L. 2011. “A Stroll with Lucilius: Horace, Satires 1.9 Reconsidered.” AJP 132: 429-55. 2015. Roman Satire and the Old Comic Tradition. Cambridge: Cambridge University Press.

Freudenburg, Kirk. 1993. The Walking Muse: Horace on the Theory of Satire. Princeton: Princeton University Press. . 2001. Satires of Rome: Threatening Poses from Lucilius to Juvenal. Cambridge: Cambridge University Press. . 2005a. "Introduction." In The Cambridge Companion to Roman Satire, ed. Kirk Freudenburg, 1-30. Cambridge: Cambridge University Press. 2005b. “Making Epic Silver: The Alchemy of Imperial Satire." In Roman and Greek Imperial Epic, ed. M. Paschalis, 77-89. Herakleion: University of Crete. 2010. "Horatius Anceps: Persona and Self-Revelation in Satire and Song." In A Companion to Horace, ed. Gregson Davis, 271-90. Oxford: Wiley-Blackwell. 
2013. “The Afterlife of Varro's Satires in Horace's Sermones: Generic Issues in Roman

Satire." In Generic Interfaces in Latin Literature: Encounters, Interactions and Transformations, ed. T.

D. Papanghelis, S. J. Harrison, and Stavros Frangoulidis, 297-336. Berlin: De Gruyter. . 2018. “Satire's Censorial Waters in Horace and Juvenal." JRS 108: 1-15, published online

February 21, 2018: https://doi.org/10.1017/S0075435818000242.

Garbugino, Giovanni. 1985. “Il XXX libro di Lucilio.” Studi Noniani 10: 45-173. . 1990. “Il XXVI libro di Lucilio." Studi Noniani 13: 129-236.

Garcea, Alessandro, and Valeria Lomato. 2014. “Hortensius dans le Brutus: une polémique rhétorique sous forme d'eloge funèbre." In Le Brutus de Cicéron: rhétorique, politique et histoire culturelle, ed. Sophie Aubert-Baillot and Charles Guérin, 141-60. Leiden: Brill.

Goh, Ian. 2014. “An Isocratean Allusion in a Lucilian Letter (181-8M = 182-9K).” Philologus 58: 18791. 2017. “Members Only? The Non-Aggression of Phalluses in Lucilian Satire." Arethusa 50: 35-64. . 2018a. "Peacocks, Pikes and Parasites: Lucilius and the Discourse of Luxury." In Lucilius and Satire in Second-Century Rome, ed. Brian Breed, Elizabeth Keitel, and Rex Wallace, 255-78. Cambridge: Cambridge University Press. . 2018b. "Republican Satire in the Dock: Forensic Rhetoric in Lucilius." In Reading Republican Oratory: Reconstructions, Contexts, Receptions, ed. Christa Gray et al., 33-48. Oxford: Oxford University Press.

Goldberg, S. M. 2005. Constructing Literature in the Roman Republic: Poetry and its Reception. Cambridge: Cambridge University Press. 
Gowers, Emily. 1993. The Loaded Table: Representations of Food in Roman Literature. Oxford: Clarendon Press.

. 2002. "Blind Eyes and Cut Throats: Amnesia and Silence in Horace Satires 1.7." CP 97: 145-

61.

. 2009a. "A Cat May Look at a King: Difference and Indifference in Horace, Satire 6." In

Ordine e sovversione nel mondo greco e romano, ed. Gianpaolo Urso, 301-16. Pisa: ETS.

2009b. "The Ends of the Beginning: Horace, Satires I." in Perceptions of Horace: A Roman Poet

and his Readers, ed. L. B. T. Houghton and Maria Wyke, 39-60. Cambridge: Cambridge

University Press.

2012. Horace: Satires Book I. Cambridge: Cambridge University Press.

Green, C. M. C. 1997. “Free as a Bird: Varro De Re Rustica 3.” AJP 118: 427-47.

Gruen, E. S. 1992. Culture and National Identity in Republican Rome. Ithaca: Cornell University Press.

Guiraud, Charles. 1997. Varron: Économie rurale. Tome III, Livre III. Paris: Les Belles Lettres.

Hass, Karin. 2007. Lucilius und der Beginn der Persönlichkeitsdichtung in Rom. Stuttgart: Franz Steiner.

Henderson, John. 1994. “On Getting Rid of Kings: Horace, Satire 1.7.” CQ 44: 146-70.

. “Virgil, Eclogue 9: Valleydiction." PVS 23: 149-76.

Hendrickson, G. L., and H. M. Hubbell. 1939. Brutus / Cicero; Orator / Cicero. Cambridge, MA: Harvard University Press.

Heslin, Peter. 2011. “Metapoetic Pseudonyms in Horace, Propertius and Ovid.” JRS 101: 51-72.

Hollis, Adrian S. 2007. Fragments of Roman Poetry, c. 60 BC-AD 20. Oxford: Oxford University Press.

Hooper, W. D., and H. B. Ash. 1934. On Agriculture / Marcus Porcius Cato; On Agriculture / Marcus

Terentius Varro. Cambridge, MA: Harvard University Press.

Hopkins, Keith. 1983. Death and Renewal. Cambridge: Cambridge University Press. 
Hunter, R. L. 2009. Critical Moments in Classical Literature: Studies in the Ancient View of Literature and its Uses. Cambridge: Cambridge University Press.

Jaeger, Mary. 2015. “Why is There No Cheese in Horace's Satires? And Related Questions for Vergil and Varro." AJP 136: 63-90.

Jocelyn, H. D. 1995. "Horace and the Reputation of Plautus in the Late First Century BC." In Homage to Horace: A Bimillenary Celebration, ed. S. J. Harrison, 228-47. Oxford: Clarendon Press.

Jones, P. J. 2005. Reading Rivers in Roman Literature and Culture. Lanham, MD: Lexington Books.

Krenkel, Werner. 1970. Lucilius: Satiren. 2 vols. Leiden: Brill.

Kronenberg, Leah. 2009. Allegories of Farming from Greece and Rome: Philosophical Satire in Xenophon, Varro, and Virgil. Cambridge: Cambridge University Press.

Kruschwitz, Peter. 2010. “Gallic War Songs: Furius Bibaculus' Annales Belli Gallici.” Philologus 154: 285-305.

Larmour, D. H. J., and Diana Spencer. 2007. “Introduction-Roma, recepta: A Topography of the Imagination." In The Sites of Rome: Time, Space, Memory, ed. D. H. J. Larmour and D. Spencer, 160. Oxford: Oxford University Press.

Lefèvre, Eckard. 2001. "Lucilius und die Politik." In Der Satiriker Lucilius und seine Zeit, ed. Gesine Manuwald, 139-49. Munich: C. H. Beck.

Lewis, Sian, and Lloyd Llewellyn-Jones. 2017. The Culture of Animals in Antiquity: A Sourcebook with Commentaries. London: Routledge.

Lowrie, Michèle. 2009. Writing, Performance, and Authority in Augustan Rome. Oxford: Oxford University Press.

Magie, David. 1950. Roman Rule in Asia Minor to the End of the Third Century After Christ. Princeton: Princeton University Press. 
Marx, Friedrich. 1904-5. C. Lucilii Carminum Reliquiae. 2 vol. Leipzig: Teubner.

Miller, J. F. 2009. Apollo, Augustus, and the Poets. Cambridge: Cambridge University Press.

Morgan, J. D. 1992. “Lucilius and his Nose (Pliny, N.H., Praef. 7)." CQ 42: 279-82.

Nelsestuen, G. A. 2015. Varro the Agronomist: Political Philosophy, Satire, and Agriculture in the Late Republic. Columbus: Ohio State University Press. . 2017. "Varro, Dicaearchus, and the History of Roman Res Rusticae." BICS 60: 21-33 [=

Varronian Moments, ed. Valentina Arena and Fiachra Mac Góráin]

Oberhelman, Stephen, and David Armstrong. 1995. "Satire as Poetry and the Impossibility of

Metathesis in Horace's Satires." In Philodemus and Poetry. Poetic Theory and Practice in Lucretius,

Philodemus, and Horace, ed. Dirk Obbink, 233-54. Oxford: Oxford University Press.

Olshausen, Eckard. 2001. “Lucilius und seine Zeit.” In Der Satiriker Lucilius und seine Zeit, ed. Gesine Manuwald, 166-76. Munich: C. H. Beck.

Purcell, Nicholas. 1995. "The Roman villa and the Landscape of Production." In Urban Society in Roman Italy, ed. T. J. Cornell and Kathryn Lomas, 151-79. London: Routledge.

Putnam, M. C. J. 1995/6. “Pastoral Satire." Arion 3: 303-16.

Raschke, Wendy. 1979. “The Chronology of the Early Books of Lucilius.” JRS 69: 78-89.

Schlegel, Catherine. 2005. Satire and the Threat of Speech: Horace's Satires, Book 1. Madison: University of Wisconsin Press. . 2010. “Horace and the Satirist's Mask: Shadowboxing with Lucilius." In A Companion to Horace, ed. Gregson Davis, 253-70. Oxford: Wiley-Blackwell.

Sciarrino, Enrica. 2007. “The Elder Cato and Gaius Gracchus: Roman Oratory before Cicero." In $A$ Companion to Roman Rhetoric, ed. William Dominik and Jon Hall, 54-66. Oxford: Wiley-Blackwell. Scodel, Ruth, and R. F. Thomas. 1984. “Virgil and the Euphrates.” AJP 105: 339. 
Skinner, M. B. 2003. Catullus in Verona: A Reading of the Elegiac Libellus, Poems 65-116. Columbus: Ohio State University Press.

Spencer, Diana. 2010. Roman Landscape: Culture and Identity. Cambridge: Cambridge University Press.

Starks, J. H. Jr. 2013. “opera in bello, in otio, in negotio: Terence and Rome in the 160s BCE." In A Companion to Terence, ed. Antony Augoustakis and Ariana Traill, 132-55. Oxford: WileyBlackwell.

Steel, Catherine. 2006. Roman Oratory, New Surveys in the Classics 36. Cambridge: Cambridge University Press. 2007. "Lost Orators of Rome." In A Companion to Roman Rhetoric, ed. William Dominik and Jon Hall, 237-49. Oxford: Wiley-Blackwell.

Stevens, B. E. 2013. Silence in Catullus. Madison: University of Wisconsin Press.

Stroup, S. C. 2010. Catullus, Cicero, and A Society of Patrons: The Generation of the Text. Cambridge: Cambridge University Press.

Svarlien, John. 1994. “Lucilianus Character.” AJP 115: 253-67.

Tatum, W. J. 1997. “Friendship, Politics, and Literature in Catullus: Poems 1, 65 and 66, 116.” CQ 47: $482-500$.

Thomas, R. F. 2009. “Homeric Masquerade: Politics and Poetics in Horace's Apollo.” In Apolline Politics and Poetics, ed. Lucia Athanassaki, R. P. Martin, and J. F. Miller, 329-352. Athens: Hellenic Ministry of Culture. 2012. Horace: Odes IV and Carmen Saeculare. Cambridge: Cambridge University Press.

Turpin, William. 1998. “The Epicurean Parasite: Horace Satires 1.1-3.” Ramus 27: 127-40. 
Van der Blom, Henriette. 2010. Cicero's Role Models: The Political Strategy of a Newcomer. Oxford: Oxford University Press.

Warmington, E. H. 1938. Remains of Old Latin, III: Lucilius, The Twelve Tables. Cambridge, MA: Harvard University Press.

Wilamowitz-Möllendorf, Ulrich v. 1900. "Asianismus und Atticismus." Hermes 35: 1-52.

Williams, Gordon. 1995. “Libertino Patre Natus: True or False?” In Homage to Horace: A Bimillenary Celebration, ed. S. J. Harrison, 296-313. Oxford: Clarendon Press.

Wiseman, T. P. 2010. “The Two-Headed State: How Romans Explained Civil War.” In Citizens of Discord: Rome and its Civil Wars, ed. Brian Breed, Cynthia Damon, and Andreola Rossi, 25-42. Oxford: Oxford University Press.

Wisse, Jakob. 1995. “Greeks, Romans, and the Rise of Atticism.” In Greek Literary Theory after Aristotle, ed. J. G. J. Abbenes, S. R. Slings, and Ineke Sluiter, 65-82. Amsterdam: VU University Press.

Woodman, Tony. 2012. “A Covering Letter: Poem 65.” In Catullus: Poems, Books, Readers, ed. I. M. le M. Du Quesnay and Tony Woodman, 130-52. Cambridge: Cambridge University Press.

Yona, Sergio. 2017. Epicurean Ethics in Horace: The Psychology of Satire. Oxford: Oxford University Press.

Zetzel, J. E. G. 2002. “Dreaming about Quirinus: Horace's Satires and the Development of Augustan Poetry." In Traditions and Contexts in the Poetry of Horace, ed. Tony Woodman and Denis Feeney, 38-52. Cambridge: Cambridge University Press.

Zucchelli, Bruno. 1977. L'Indipendenza di Lucilio. Parma: Università degli Studi di Parma.

NOTES 
${ }^{1}$ See Freudenburg 2005a, 1-2 for the importance of the quidem and the tendentiousness of this claim; more in Freudenburg 2013, 298-9. It has not been recorded enough that Quintilian, in expressing a preference for Horace over Lucilius, who is valued by his admirers because (it seems) of his Romanness (Freudenburg 2005b, 81), may "disagree with Horace" (ab Horatio dissentio) and yet still make a joke based on the river metaphor which is central to this article: Horace is terser, purer, and better, "unless I am slipping up (sc. in the mud!) because of my affection for him" (nisi labor eius amore).

2 See e.g. Delignon 2006 and Ferriss-Hill 2015.

${ }^{3}$ See Kronenberg 2009, 73-129. Freudenberg 2013 is a good entrée to the difficult subject of the relationship between Varro's Menippean Satires and Horace's Satires; perhaps especially relevant for this argument is the analysis of the Cynic flavor Varro's Menippeans might lend to Sat. 1.1 (311-13). ${ }^{4}$ Translations of Lucilius are from Warmington 1938, of Cicero's Brutus and Orator from Hendrickson and Hubbell 1939, of Horace Satires 1 from Brown 1993, and in the case of Varro De Re Rustica 3 from Hooper and Ash 1934, sometimes with light edits. Others are mine.

${ }^{5}$ Gowers 2012, 157: “alludes most obviously to Callimachus' tirade against the muddy Euphrates versus the pure spring."

${ }^{6}$ See e.g. Strabo 16.1.9: "The country is intersected by many rivers, the largest of which are the Euphrates and the Tigris: next to the Indian rivers, the rivers in the southern parts of Asia are said to hold the second place."

${ }^{7}$ The latter is a marked locus, generally seen as an allusion to Callimachus' mention of the Euphrates six lines from the end of his Hymn to Apollo since Scodel and Thomas 1984.

${ }^{8}$ See Edwell 2013 on the status of the Euphrates as an Asian border. 
${ }^{9}$ Freudenburg 1993, 158-62 notes that the allusion is "a sensible claim considering the closeness of the parallel" (158). Heslin 2011 documents a coterie of poets playing games with faux-geographical names in a fashion similar to the techniques posited here, with Horace on the receiving end (55-60). ${ }^{10}$ Piscinarii are criticized by Cicero in a series of letters to Atticus (who is friends with them): Att. 1.18.6, 1.19.6, 1.20.3, and 2.1.7. In the last he "waxes satirical" (Dyck 2008, 160) about how the "leading men think they can reach heaven (se caelum attingere) if there are bearded mullets in their ponds that come to their hands (sc. for food)." It may be a stretch, but I would love to see this as a reminiscence of Lucilius' Lupus ("sea-bass") on trial in heaven in his Book 1 Concilium deorum. ${ }^{11}$ Varr. R.R. 3.2.17 features an Abuccius who wrote Luciliano charactere libelli ("little books in the Lucilian manner," cf. Svarlien 1989), in the discussion of the profitability of smallholdings now that Rome is given to luxury, which motivates the subsequent theme; Lucullus' fishponds and peacock feature soon after, but this Varronian book is rarely mentioned in the same breath as Horace Satires 1: for instance, Brink 1963 passes over it entirely in his paper on Varronian and Horatian literary theory. Cucchiarelli 2001, 24 cites Varr. R.R. 3.3.10, in commenting on Murena ("lamprey") and Capito ("mullet") at Hor. Sat. 1.5.38, as does Gowers 2012, 196, but they go no further. Cf. Purcell 1995, 153: "all of this sets us in the same sort of world as the satires of Horace and Persius." 12 While Kronenberg 2009, 128 seems to be alone in ascribing this behavior to Hortensius rather than L. Lucullus, at the very least Hortensius strongly approves of the practice. It is unclear whether the moralizing comment immediately following this passage, that he "became so enthusiastic that he allowed the architect to spend money as if it were his own" (R.R. 3.17.9)-on which see Nelsestuen 2015, 210, who reads it as a failure to reconcile pleasure and profit-is spoken by Axius of Lucullus (as Nelsestuen has it), by Hortensius of Lucullus, or by Axius of Hortensius. 
${ }^{13}$ Varro claims in propria persona to do the same for his own sheep at R.R. 2.2.9, so this practice is overtly a function of approbation, authorship, and authority. On the qualified version of Horace's Apulian heritage at Sat. 2.1.34, Lucanus an Apulus anceps, "whether as Lucanian or Apulian," see Freudenburg 2010, 276-7.

14 Putnam 1995/6, reviewing Freudenburg 1993, is an excellent treatment of such occasions.

${ }^{15}$ Cf. Kronenberg 2009, 106 on the oddity of Axius' moralizing position, and see Nelsestuen 2017, 32-3 on the questionable morals of pastio uillatica, the "animal husbandry of the villa," Varro's subject in R.R. 3.

16 See Gowers 2012, 245, cf. Jaeger 2015, 75-6.

${ }^{17}$ The mules which appear soon after the last extract (R.R. 3.17.7) are Hortensius' own, but they are being exploited for a pun on mula $\sim$ mullus.

${ }^{18}$ Cf. Gowers 1993, 20: “Where Greece had scientific discoveries, Rome had culinary ones.” Nelsestuen 2015, 193 sees peafowl in Varro as an example of pleasure leading to profit. Aristoph. Ach. 63 associates peacocks with Persian ambassadors; Clement of Alexandria Paedag. 3.4.30 and the scholia to Aristophanes corroborate the link with Persia; Lucian Nav. 23, Aelian N.A. 13.18, and Quint. Curt. 9.1.13 note an Indian origin. For these and other references, see Arnott 2007, 136, 236. Plin. N.H. 10.43 notes the anthropomorphic vanity of the bird (see Lewis and Llewellyn-Jones 2017, 276), which may match a Hortensian (Lucilian?) self-regard.

${ }^{19}$ Horace does regularly depict Lucilius eating, though: Gowers 2012, 136; Anderson 1982, 32-3. Goh 2018a questions the standard portrait of a sternly moralizing and abstemious Lucilius, with peacocks on the menu at $267-71$. 
20332 Warmington = 304 Marx: hoc est cum psolocopumai ("that's when I'm hit with an erection"): see Gowers 2012, 114, cf. Goh 2017, 44-7. Additionally, tument could anticipate lutulentus.

${ }^{21}$ Plut. Cat. Min. 25 (marriage); 52.3-4 (Caesar's invective on Cato motivated by inheritance); Caes. 14 for Cato's hypocrisy, protesting marriages of alliance: see Hopkins 1983, 87-8, cf. Fantham 2003, 103. ${ }^{22}$ Gowers 2012, 98, with references. For Horace's speaker as compromised, see e.g. Turpin 1998. ${ }^{23}$ Note, though, that Hortensius had ended up estranged from his own son: Dyck 2008, 163. Cf. Dugan 2005, 216-8 for Cicero; Schlegel 2005, 38-40, 49-51 has good comments on how Lucilius, Horace's literary father in Sat. 1.4, is replaced in that poem by Horace's biological father (and both will be replaced by Maecenas). At Brut. 330 Eloquence is depicted as an orphaned (orbae) child, now that Hortensius is dead, and Cicero and company must be her new guardians.

${ }^{24}$ See Plin. N.H. 8.211 on Lucullus and Hortensius as being in the vanguard of those who kept wild boar reserves. Cf. Doody 2017, 198 on Varro's deployment of anecdotes such as this one about Hortensius as a "sort of dubious aside."

${ }^{25}$ Coleman 1990, 67 merely calls it “a concession to practical considerations."

${ }^{26}$ Green 1997, 440 sees here a proof of the extent of Rome's empire, whereby Hortensius overrules foreign poetry in the service of the banquet and domesticates the hunt. "Thracian" is the secure emendation of Keil where the manuscripts present grave difficulties: Guiraud 1997, 94.

${ }^{27}$ Larmour and Spencer 2007, 52 identify the implications of the "raised position of the spectators" in creating an arena. Spencer 2010, 83 notes "the frisson of danger" in this "Golden Age fantasy." Hortensius, like Lucilius (Hor. Sat. 1.10.20-1), has to do with Greek words in a Latin setting, as he prefers a Greek designation (therotrophium) to the Latin name (leporarium) for his game-preserve: see 
Nelsestuen 2015, 190 on this "topos of Greek loanwords as a symptom of increased luxury," with more at 194-5; cf. Guiraud 1997, 95 on this likely "pédantisme hellénisant d'Hortensius."

${ }^{28}$ Cucchiarelli 2001, 50-1 esp. n.114 despatches the history of the trope, involving Cratinus, Aristophanes and Homer, with aplomb; see also Gowers' note $(2012,157)$ on lutulentus. Cucchiarelli 2001, 26-33 well discusses the swamps of Hor. Sat. 1.5 as a reminiscence of Aristophanes' Frogs, and those too could be a version of the muddy river: Cucchiarelli links the swamp to Lucilius' "Journey to Sicily" at 58-60. For the Old Comedians Cratinus and Aristophanes engaging in poetic fights over drinking water or wine (Ar. Eq. 526-36, with Cratin. fr. 203), and for Cratinus' self-presentation as a torrential flow (fr. 198), with relevance to the contest of new versus old poetry, see Bakola 2010, 1629.

${ }^{29}$ There are many good scholarly treatments of the issue, starting with Wilamowitz-Möllendorf 1900, which include commentators on Dionysius of Halicarnassus, whom I do not treat because it would require detailed investigation of Horace's relationship with his work. For Atticism especially, see in English Bowersock 1979, especially 59-65; Wisse 1995; and Connolly 2007.

30 See Dugan 2005, 169-71 for how the De Oratore ends with a prediction of Hortensius' future dominance of oratory, which only serves to redound to Cicero's even greater credit.

${ }^{31}$ Steel 2007, 244 developing Steel 2006, 57-9. The aim is to draw criticism away from Cicero, who had been accused of being an Asianist by the Atticists: see e.g. Dyck 2008, 167-8.

${ }^{32}$ It is relevant that Horace poses a rhetorical question of Lucilius, “Doesn't he laugh at lines of Ennius of inferior dignity?" (non ridet uersus Enni grauitate minores, 1.10.53). Perhaps Lucilius can be mocked for having inferior dignity when he criticized others for lacking dignity. 
${ }^{33}$ See Cuypers 2010, 328-30 on the two kinds of Asianism just discussed: "The key similarity is that they are both extreme and therefore bad" (329). For appreciation of style such as Asianism in the ears of the beholder, see Cic. Orat. 71 with Garcea and Lomanto 2014, 158-9.

${ }^{34}$ On Rhodians stigmatized as profligate at Ter. Eun. 420-33, see Starks 2013, 136-8. Cf. Dugan 2005, 225-6 on Cicero's careful defensiveness about his training in Asia not being Asianist (and indeed Rhodes itself represents, as Cicero wants for himself, a middle way between Atticism and Asianism). ${ }^{35}$ For a list of surprisingly young senes see Cameron 1995, 175-81. Lucilius' habit of declaiming stans pede in uno (meaning "with ease," but literally "on one leg," Sat. 1.4.10) has an air of unwieldy and undignified acrobatics (i.e. askoliasmos: Gowers 2012, 156).

${ }^{36}$ Douglas 1966, 231 suggests that remanebat idem nec decebat idem, "the same [style] remained but was not fitting" (Brut. 327) is a parody of Hortensius' style; perhaps we might compare the unnecessary repetition of ut magnum ... ut multum ("as a big deal ... however much it was," Hor. Sat. 1.4.10, 1.4.13).

${ }^{37}$ Cf. Freudenburg 1993, 158-9 for the ways Cicero relates theories concerning word arrangement, relevant to Horace's durus componere uersus (Sat. 1.4.8) judgement, to the river metaphor; the argument there foreshadows that here in some respects. See also Jones $2005,51-4$ on rhetoric as a river in Quintilian and others.

${ }^{38}$ Cf. Cic. Orat. 230: Asiaticos maxume numero seruientis, "particularly the 'Asiatics' who are slaves to rhythm."

${ }^{39}$ Cavarzere 2000, 87-8, although Courtney 1999, 132-3 is more circumspect. Sciarrino 2007, 60-4 goes beyond the Ciceronian perspective.

${ }^{40}$ Discussion in Oberhelman and Armstrong 1995, cf. Chahoud 2011, 368-9. 
${ }^{41}$ If such weakness is a marker of effeminacy, then it resonates with the personification of Eloquence, comprehensively treated by Stroup (2010, 256-64), in the Brutus as a vulnerable female who wandered, as Cicero had, around Asia (Brut. 51); "she ended up smearing herself with foreign practices (se externis oblineret moribus)" - cf. Horace's own emphasis on smearing (illinere, Sat. 1.4.36, 1.5.30-1).

42 There is the possibility of a pun relevant to the argument in senis, which could also mean "of an old man," despite the different metrical quantities of senex and senus: Gowers 2012, 330.

${ }^{43}$ And therefore unlike Vergil (molle atque facetum, 1.10.44): see Freudenburg 2001, 35 and Zetzel 2002, 45-8, who notes the undercutting note of effeminacy at 46.

${ }^{44}$ Dugan 2005, 231, with 122, and 220 n.146; Hortensius is accused of gesturing like a pantomime actress (Gell. 1.5.3 = ORF 39): see e.g. Corbeill 2004, 152, and Garcea and Lomanto 2014, 147-8. Hortensius had the forum as his "theater" (Brut. 6); Horace disparagingly links Lucilius' poems to Laberius' mimes (Sat. 1.10.5-6).

${ }^{45}$ Cf. the verb's use with faex by Cato (Agr. 152) and limus by Horace (Sat. 2.4.80). Cicero's metaphor of the fading picture could be relevant to Horace's Sat. 2.1 description of the result of Lucilius' writing being "that the whole existence of the old man lies open like a painted votive tablet" (2.1.34, trans. Anderson 1982, 31): cf. Freudenburg 2010, 274-5, 278. Hortensius' decline is troped as involving clothing: his speech was "now no longer dressed up (uestitu ... ornata) with the same richness of language as formerly" (Brut. 327); cf. perhaps Hor. Sat. 2.1.64, where Lucilius is described as "tearing off the hide" (detrahere ... pellem) of his targets.

${ }^{46}$ The river Aufidus could also be associated with foreignness, as it was also known as the river Canna (cf. Thomas 2012, 252 on Hor. C. 4.14.25-30), and thus the site of Roman defeat at the hands of 
their enemy Hannibal. Liv. 22.44 has the Carthaginians creating internal Roman dissension between the two riverbank camps over obtaining drinking water; Hannibal would line up his forces near the river, hindering the Romans' movement and countering their numerical advantage (Daly 2002, 32-7, cf. Liv. 22.47); the battle's result was that the river ran with blood, a stream of it crossed by Hannibal on a bridge of bodies (see e.g. Flor. 2.6.18, Val. Max. 9.2 ext. 2): shades of the Euphrates? Cf. Marcius' first prophetic song at Liv. 25.12: "Flee the river of Canna, Trojan-born, lest the foreigner force you to join battle in the plain of Diomedes."

${ }^{47}$ Freudenburg 1993, 190: "greed has taken on a distinctly poetic color." For Hortensius as rhetorically copiosus, see Brut. 303, with Garcea and Lomanto 2014, 147.

${ }^{48}$ That said, all the protagonists of Sat. 1.7 are tarred with the same brush: Rex is a durus / uindemiator ("a tough vine-dresser," Sat. 1.7.29-30), and Brutus' name suggests ferocity (Henderson 1994, 162). See Goh 2018b, 38 for Sat. 1.7 as a rewrite of Lucilius Book 2, the courtroom battle of Albucius and Mucius Scaevola.

${ }^{49}$ Schlegel 2005, 81 thinks that both Rupilius and Persius remind us of Lucilius. Lucilius is on record as having joked about the dialect of Praeneste, Rupilius' place of origin (1.7.28): cf. Quint. Inst. 1.5.55. ${ }^{50}$ Cf. Henderson 1994, 155-6 on how the reference to Diomedes vs. Glaucus (Sat. 1.7.15-16) is part of an exchange of "Homeric 'gold' for Lucilian 'bronze'."

${ }^{51}$ Cf. Cic. Pis. 1, with OLD s.v. lutulentus 2. The word is rare in Cicero; see Crawford 1994, 152-4, on Pro Q. Gallio fr. 1, where it is the floor at a party (possibly involving Cicero's opponents) that is immunda and lutulenta uino. Freudenburg 2018 picks up on the function of Roman censors to manage water rights, which gives point to the mud metaphor. 
${ }^{52}$ Cf. the more political reasons given by Du Quesnay 1983, 37. Hortensius had defended the king of Bithynia in his youth: Cic. De Orat. 3.229.

53 "Swollen Alpine man," identified by ps.-Acro, though see Kruschwitz 2010, 290-1. See also Heslin 2011, 52-3, who accepts the identification. Furius could be the friend of Aurelius who memorably features in Cat. 11, 16, 23 and 26, though as Stroup 2010, 283 notes "the utter lack of evidence makes it totally unable to be proved."

${ }^{54}$ Memnon is Asian too: he is associated with Susa in Herodotus $(5.53-4,7.151)$ and Aeschylus (Pers. 17, 118, apud Strabo 15.3.2) and indeed in Diodorus (2.22), who claims that it was the king of Assyria who sent Memnon to Priam to fight at Troy, after building a palace in Susa.

${ }^{55}$ In Sat. 2.5 Furius "swollen with rich tripe" (pingui tentus omaso) returns as an obstacle for the poet, with another mention of the Alps (40-1), shortly before reference is made to how "more tuna will swim up and the fishponds will grow" (2.5.44).

56 See e.g. Tatum 1997, 489-90, though see Stroup 2010, 279-80; cf. Courtney 1993, 230-2, Skinner 2003, 20 with 196 n.44, and Hollis 2007, 155-7 on Hortensius as a composer of erotic verse. Varro (wrongly) reports that Hortensius was the first to use ceruix in the singular (L.L. 8.14, 10.78, followed by Quint. Inst. 8.3.35); perhaps Horace acknowledges Varro's judgement with ardua ceruix (“how long the neck") at line-end, Sat. 1.2.89. For Cat. 65-118 as a poetry book framed by a reversal of Callimachus' Aetia, see Barchiesi 2005, 333-6, who notes, attractively for my position on Hortensius, that "the idea of beginning a Roman book of elegiacs with the sequence 65-7 can only be described as a satiric transformation" (336).

${ }^{57}$ Du Quesnay 2012, 160, followed by the attractive suggestion that Hortensius was deeply involved in negotiations to reinstate Ptolemy XII to the throne in Egypt (161). If Hortensius in Cat. 95 is the 
orator, and the "five hundred thousand in one" (95.3) refers to his ease of composition (see e.g. Feldherr 2011, 102), that line (sadly lacking the associated pentameter) could be a prefiguration of Lucilius' "two hundred verses" delivered with ease (Hor. Sat. 1.4.9, 1.10.60-1); while Courtney 1993, 231 and Hollis 2007, 156 both support emending Hortensius out of the poem, I am inclined to refrain from tampering with this manuscript reading.

${ }^{58}$ For markers of doubt, see Woodman 2012, 132-3 on the very first word of the poem, the un-poetic etsi ("even if").

59 The image focuses on forgetfulness (cf. Lowrie 2009, 41), and is "small, almost unspeakably pathetic" (Stevens 2013, 171) - though Woodman 2012, 138 notes the oddity of fluctuat, "suited to describing someone crossing a turbulent river by boat."

${ }^{60}$ See Morgan 1992 for the corruptions in this passage, which I have cited as in Marx (cf. 635 Warmington $=592-3$ Marx $)$.

${ }^{61}$ Persius is also comparable to the grammarians of Sat. 1.10 as well as Valerius Cato from its spurious opening lines. There may be another Callimachean reference lurking: in Callimachus' "Reply to the Telchines," the poet desires that those rebarbative critics "not judge learned poetry

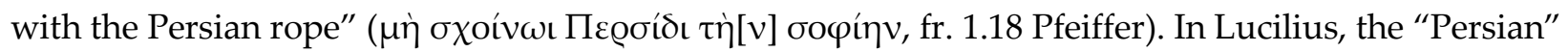
(Persicus minus a "c") actually is oọós; cf. Henderson 1994, 155. Andrews 1998 has, among others, noted the satirical character of the Aetia Prologue.

62 There are two mentions of a Hortensius in Lucilius' extant corpus: a Hortensius, in Lucilius Book 2, is a lackey of Q. Mucius Scaevola who apparently exhumed a man buried alive in Asia (73-4 Warmington = 60-1 Marx, cf. Goh 2018b, 45), and another line, involving the palaestra ("wrestlingschool") as good for the buttocks (1180 Warmington = 1267 Marx); Cichorius 1908, 339-40 argues 
that the latter addressee was the orator Hortensius' father, but certainty is lacking, so any link of Hortensius to satire or Horace's Satires 1 is unprovable.

${ }^{63}$ See e.g. Zucchelli 1977, 84; Hass 2007, 55-6. The language of trade, which seems to present Lucilius as a commodity, is bound up with the name-check; Goldberg 2005, 167 comments on Lucilius' apparent mercantilism in other contexts.

64 That said, Marx 1904-5, 2.244 thinks the related lines - related to the extent that Garbugino 1990, 168-70 runs them together with this fragment-at libertinus, tricorius, Syrus ipse, at mastigias / quicum uersipellis fio et quicum conmuto omnia ("but he is a freedman, a three times thick-skinned rascal, a very Syrian, but he's a rogue with whom I become a shape-changer and with whom I exchange everything," 652-3 Warmington =669-70 Marx), which themselves contain an eastern outsider, are such a subversion that they must be spoken by somebody else. See Goldberg 2005, 168-9 for problems with both sets of lines.

${ }^{65}$ Cichorius 1908, 72-7, cf. Appian B.C. 5.4, Cic. Verr. 3.12. Raschke 1979, $82-3$ and Christes 1986, 70 put it earlier, in 131 B.C.E. Krenkel 1970, 2.377 has 129 B.C.E. as the terminus post quem. Lefèvre 2001, 142 sits on the fence, though Olshausen 2001, 173 in the same volume seems to adopt the earlier dating. Whatever the dating, Asia itself was topical for Lucilius: Attalus III (who died young) bequeathed Asia to Rome in his will (another piece of writing!) of 133 B.C.E., at the beginning of Lucilius' satirical career: Christes 1971, 31-4.

${ }^{66}$ See Yona 2017 for Epicureanism in Horace's Satires. Contenders for the prize for long-windedness in Horace's Satires are Stoic: Crispinus (Sat. 1.1.120, 1.4.14-16), Fabius (Sat. 1.1.13-14, 1.2.134) and Damasippus (Sat. 2.3). Lucilius, when Horace calls him long-winded, is discredited as a Stoic for 
lacking style as well as sense. See Goh 2018b, 47-8 for Lucilius' supposed "plain style" as Stoic oratory. Hortensius was well known for disdaining philosophy: Garcea and Lomanto 2014, 149-50. ${ }^{67}$ Cf. Brut. 326: "all the younger generation was filled with admiration, and the people were carried away by it" (as by a river?). Yet it is noteworthy that Cicero does align himself with Hortensius as being minime uolgare ("far from commonplace:" Hortensius at Brut. 302, Cicero at Brut. 321): Garcea and Lomanto 2014, 152-3. How "common" was Lucilius, friend of the good and great (Scipio, Laelius), compared to Horace?

${ }^{68}$ See Wiseman 2010, 25-6, who also moves swiftly from Horace to this Varro fragment.

${ }^{69}$ Cf. Du Quesnay 1983, 30-1 on Lucilius as perhaps associated with Pompeians.

${ }^{70}$ Such misremembering is the more ironic given Hortensius' perfect recall: Cic. Brut. 301, elaborated at 303. On Lucilian self-regard in the publicanus fragment, cf. Hass 2007, 109.

${ }^{71}$ See e.g. Gowers 2009a, 302-5 on Horace as a scriba quaestorius, with Armstrong 1986, 263-7 and Williams 1995. Cucchiarelli 2001, 63 also connects Horace as scriba to the publicanus fragment. 72 See e.g. Magie 1950, 165: “The publicani had despatch-bearers of their own, who carried communications to and from the Capital and through whom letters could be sent by persons of influence even though they were not connected with the companies."

${ }^{73}$ See Goh 2014 for discussion, and compare 1063 Warmington = 1027 Marx, with n.76 below.

${ }^{74}$ Whatever it is: Gowers 2012, 308, 338, cf. OLD s.v. subscribo 4 "(of the censors) To enter (an alleged offence) under the name of a person on the roll." This intersects with the censor's "black mark" at Hor. Sat. 1.4.5, for which see Freudenburg 2018, 3-8.

${ }^{75}$ Another relevant line of Lucilius calls "togas and tunics all the dirty work of the Lydians" (praetextae ac tunicae: Lydorum opus sordidum omne, 12 Warmington = 12 Marx). Here, Roman 
garments end up eastern, and while "Lucilius trains his fire on Hellenic affectations, rather than on Hellenism" (Gruen 1992, 307), Horace can hint at the putative foreignness of his predecessor if we accept that Roman things like satire can have a foreign origin. The emphasis on the clothing having been soiled may link it with Horace's muddy slur of lutulentus.

${ }^{76}$ Preserved by Nonius; see Garbugino 1985, 161-2 on the two theories adopted to explain the re- of rescribere, of which I find (like him) the epistolary theory more likely.

77 Varro L.L. 7.20, etymologically explaining ambages. Cf. Hass 2007, 209 n.173: the interpretation advanced there (that Lucilius refuses to write to commission) could be linked to Horace's charge of Lucilius" "laziness" (piger, Sat. 1.4.12).

${ }^{78}$ Cf. Brut. 321, where Cicero stresses his own frequent use of the pen as an aid to self-improvement, with Dugan 2005, 229-30.

${ }^{79}$ I do not comment on the debate over what, if anything, Hortensius actually said at the trial.

${ }^{80}$ There are some near-misses, identified by commentators such as Porphyrio and ps.-Acro: see for example 101 Warmington = 1207 Marx, adapted in Hor. Sat. 1.6.106, with Schlegel 2010, 265.

${ }^{81}$ On Hortensius as an exemplum for Cicero, see van der Blom 2010, 254-6.

${ }^{82}$ Combining Schlegel 2005, 118, who comments nicely that rapit ("snatched," 1.9.77) translates $\dot{\varepsilon} \xi \eta \dot{\varrho} \pi \alpha \xi \varepsilon v$ more closely than seruauit, and Henderson 1998, 171 on the invocation of both Homer and Lucilius serving as "poetic protection," exemplifies the double vision here; see Schlegel 2010, 259 on the homogenisation of the Greek original, so as not to mix Latin and Greek as Lucilius is accused of doing in Sat. 1.10. Miller 2009, 44 lists other Homeric versions of the phrase; Thomas 2009, 332-3 adds Brutus again (alongside Vergil) to the allusive texture. 
${ }^{83}$ Cf. Att. 3.8.4, 3.9.2, QFr 1.3.5-8, with Dyck 2008, 159-61; there are later fallings out and reconciliations of the two, which end with Cicero's expression of pathos (excrucior, "I am tormented") on hearing of Hortensius' last illness (Att. 6.6.2).

${ }^{84}$ On Maecenas' Etruscan background, see Chillet 2016, 21-167; for his Catullus-influenced poetry, Courtney 1993, 276-81 and Hollis 2007, 314-25. Gowers 2012, 331 is right to note that "Etrusci carefully rules out identification with the proscribed assassin of Caesar;" Cassius the assassin does not appear in the Brutus, but when Horace Satires 1 was published the name Cassius would have been most associated with Brutus. Cassius the Etruscan, otherwise unknown, but recently dead, may fleetingly resemble Hortensius, recently dead in the Brutus, as well. Freudenburg 2018, 7 points out that in Satires 1 the "Italian writers of dubious talent are ... marked as immigrants who have made their way to Rome from far off places," unlike Horace's friends.

${ }^{85}$ See Gowers 2002, 149-50 on hints of Cicero in Satires 1; updates at Gowers 2009b, 40-4, 48-52, 5660 on (philosophical) beginnings and ends. More generally: Feeney 2002, 13-18.

${ }^{86}$ Himself an onrushing figure, as much river as seruus currens: see Jocelyn 1995, Hunter 2009, 99 100, and Freudenburg 2013, 327-32.

${ }^{87}$ I owe this formulation in part to an anonymous reader. I would like to thank the anonymous readers, the editor of $A J P$, an audience at the University of Manchester in 2014, the students on a Roman satire module at Swansea University in 2018, Brian Breed, Tom Geue, Emily Gowers, Emily Kneebone, Marden Nichols, and Tamasine Preece. 